\title{
AN INTEGRATED FINANCING SYSTEM FOR PURCHASE MONEY COLLATERAL: A PROPOSED SOLUTION TO THE FIXTURE PROBLEM UNDER SECTION 9-313 OF THE UNIFORM COMMERCIAL CODE*
}

\author{
MORRIS G. SHANKER广்
}

Two important commercial states have recently reacted in rather violent fashion to Section 9-313, the fixture section, of the Uniform Commercial Code. California refused to adopt Section 9-313 when it enacted the Code, ${ }^{1}$ and Ohio, after living with Section 9-313 for about a year, decided to revise it

†Associate Professor of Law, Western Reserve University; Visiting Associate Professor of Law, University of Michigan, 1964.

"Section 9.313. Priority of Security Interests in Fixtures.

(1) The rules of this section do not apply to goods incorporated into a structure in the manner of lumber, bricks, tile, cement, glass, metal work and the like and no security interest in them exists under this Article unless the structure remains personal property under applicable law. The law of this state other than this Act determines whether and when other goods become fixtures. This Act does not prevent creation of an encumbrance upon fixtures or real estate pursuant to the law applicable to real estate.

(2) A security interest which attaches to goods before they become fixtures takes priority as to the goods over the claims of all persons who have an interest in the real estate except as stated in subsection (4).

(3) A security interest which attaches to goods after they become fixtures is valid against all persons subsequently acquiring interests in the real estate except as stated in subsection (4) but is invalid against any person with an interest in the real estate at the time the security interest attaches to the goods who has not in writing consented to the security interest or disclaimed an interest in the goods as fixtures.

(4) The security interests described in subsections (2) and (3) do not take priority over

(a) a subsequent purchaser for value of any interest in the real estate; or

(b) a creditor with a lien on the real estate subsequently obtained by judicial proceedings; or

(c) a creditor with a prior encumbrance of record on the real estate to the extent that he makes subsequent advances

if the subsequent purchase is made, the lien by judicial proceedings is obtained, or the subsequent advance under the prior encumbrance is made or contracted for without knowledge of the security interest and before it is perfected. A purchaser of the real estate at a foreclosure sale other than an encumbrancer purchasing at his own foreclosure sale is a subsequent purchaser within this section.

(5) When under subsections (2) or (3) and (4) a secured party has priority over the claims of all persons who have interests in the real estate, he may, on default, subject to the provisions of Part 5, remove his collateral from the real estate but he must reimburse any encumbrancer or owner of the real estate who is not the debtor and who has not otherwise agreed for the cost of repair of any physical injury, but not for any diminution in value of the real estate caused by the absence of the goods removed or by any necessity for replacing them. A person entitled to reimbursement may refuse permission to remove until the secured party gives adequate security for the performance of this obligation. 
substantially.2 Ohio objected most to Section 9-313's rule giving priority to the fixture secured party over the prior real estate mortgagee, and reversed it. Thus, under Ohio's replacement of Section 9-313 the prior real estate mortgagee is invariably favored over the fixture security interest. ${ }^{3}$ By making this change, Ohio apparently felt it was returning to its pre-Code law ${ }^{4}$ on the subject as enunciated in Holland Furnace Co. v. Trumbull Sav. \& Loan Co. ${ }^{5}$ Curiously, that case did not even deal with the conflict between the prior real estate mortgagee and the fixture security interest. In fact, the court expressly declared that its decision was limited to the rights of persons dealing with the land subsequent to affixation of the fixture. ${ }^{6}$ The few Ohio cases specifically dealing with the conflict between the prior land interest and the fixture security interest usually followed Section 9-313's approach favoring the fixture security interest, at least where removal of the fixture could be accomplished without material injury to the building. ${ }^{7}$ Thus, in rejecting Section 9-313, Ohio has not really affirmed a long-standing policy or line of decisions; it would appear, rather, that it has chosen a new, uncharted road.

1. Cal. Laws 1963, ch. 819 (effective Jan. 1, 1965); 1 CCH Installment CredrT GuIDE โ 5443 (1962).

2. See Orio Rev. CoDe tit. 13, § 1309.32 (1963), effective Oct. 8, 1963.

3. See Oнio Rev. Cone tit. 13, § 1309.32(B) (1963). This, at least, appears to be the statutory rule. It yet remains to be seen whether the Ohio courts will give full effect to its language. Other states which had formerly adopted such a rule by judicial decision often avoided it by declaring what most would think was a "fixture" actually to be "personalty." See Gilmore, The Purchase Money Priority, 76 Harv. L. Rev. 1333, 1357 (1963).

There is already Ohio authority to suggest that such an approach is possible. For example, in Standard Oil Co. v. Zangerle, 144 Ohio St. 523, 60 N.E.2d 59 (1945), it was conceded that a steam boiler plant which was useable for ordinary manufacturing businesses would normally be held to be a fixture. However, the court decided that the particular boiler plant involved was useable only in a particular business and therefore was to be deemed personalty for tax purposes.

4. "[T] he real estate lien has been restored to its pre-Code positions and the doctrine of the Holland Furnace case has been re-established." Hollander, Imperfections in Perfection of Ohio Fixture Liens, 14 W. Res. L. Rev. 683, 698 (1963). Mr. Hollander's views are of particular interest since he helped prepare House Bill 248, a bill which was a precursor of the legislation which repealed $\$ 9-313$ in Ohio. H.B. 248 was not adopted itself, but one of its basic ideas, namely that a fixture security interest should be subordinate to a prior real estate mortgage, found its way into Amended House Bill 565 which finally passed the Ohio legislature.

5. 135 Ohio St. 48,19 N.E.2d 273 (1939).

6. Id. at 57,19 N.E.2d at 277 . The precise holding of the court was that a subsequent purchaser of the real estate was not charged with constructive notice of a conditional sales contract on a furnace which had been filed only in the chattel records. Thus, such a subsequent purchaser without notice took free of the conditional sales contract. Interestingly, the subsequent purchaser in this case happened to be the prior mortgagee, who was purchasing at his own foreclosure sale.

7. See Holland Furnace Co. v. Joy, 16 Ohio L. Abs. 251 (1934) (furnace); East Ohio Bldg. \& Loan Co. v. Holland Furnace Co., 48 Ohio App. 545 (1934) (furnace); Frigidaire Sales Corp. v. Katz, 29 Ohio N.P. (n.s.) 595 (1931) (refrigeration system). 
The California response was directed more toward the confusion inherent in Section 9-313's working procedures than toward the section's policy favoring the fixture secured party. California felt that Section 9-313's treatment of fixtures would only compound an already confused area of California law. ${ }^{8}$ The pre-Code confusion at least had the advantage of familiarity, and apparently California preferred not to embark on some new road of confusion.

The reactions to Section 9-313 which took place in California and Ohio confirm that the section is a potential source of trouble. ${ }^{8}$ Calls for correction of Section 9-313's shortcomings have been many, ${ }^{10}$ but few have suggested specifically what can or should be done. ${ }^{11}$ If further reactions to Section 9-313 are to be avoided, specific workable solutions to the problems of the section must be suggested. ${ }^{12}$

\section{How Sound is the Policy Underlying Section 9-313?}

The basic policy of Section $9-313$ is that fixture financing is desirable. ${ }^{13}$ It is to be encouraged by permitting fixture secured parties who follow certain simple rules to attain priority over all other interests in the land, regardless of whether such interests arose prior or subsequent to the affixation of the fixture.

\section{A. Policy Favoring Fixture Security Interest Over Subsequent Land In- terest}

Allowing a fixture security interest, by an appropriate public filing, ${ }^{14}$ to achieve priority over persons whose rights in the land arise subsequent to the installation of the fixture seems to provoke no dissent. ${ }^{15}$ Apparently the

8. The California story is summarized in Project: California Chattel Security and Article Nine of the Uniform Commercial Code, 8 U.C.L.A.L. REv. 812, 931-42 (1961).

9. The leading article is Coogan, Security Interests in Fixtures Under the Uniform Commercial Code, 75 HaRv. L. Rev. 1319 (1962).

10. Gilmore, The Purchase Money Priority, 76 Harv. L. Rev. 1333, 1395 (1963). For a particularly strong attack on \$ 9-313, see Hollander, supra note 4; and Hollander, Real Estate and the Commercial Code, 34 Cuyanoga County (OHio) Bar Assoc. J. (Jan. 1963).

11. Coogan, supra note 9, makes some specific suggestions for minor amendments both in UCC $\$ 9-313$ and the Bankruptcy Act, for the purpose of eliminating certain bankruptcy problems which now face the fixture secured party. He also makes some broad suggestions for generally amending § 9-313.

See also Kripke, Fixtures Under the Uniform Commercial Code, 64 Colus. L. Rev. 44 (1964), which was published after this manuscript was prepared. Mr. Kripke does propose a number of specific changes for UCC \$ 9-313.

12. The author understands that a Subcommittee of the Permanent Editorial Board for the Uniform Commercial Code is now dealing with this problem. Letter from Prof. Grant Gilmore to author, Sept. 27, 1963.

13. Coogan, supra note 9 , at 1319 .

14. Filings are usually deemed appropriate only if made in the real estate records.

15. Even Ohio and California agree. See OHro Rev. Cone tit. 13, § 1309.32(B) (1963); and Project, supra note 8, at 932, 938. A problem in California, however, is how the fixture secured party, particularly a conditional vendor, goes about making an 
overwhelming, if not unanimous, view is that an appropriate public filing constitutes constructive notice of the fixture security interest to all persons who subsequently deal with the land. Such persons then have the free choice of dealing or not dealing with the land subject to the prior security interest in the fixture. If they choose to deal with the land, they will be estopped from later claiming that they made a bad bargain. ${ }^{16}$

\section{B. Policy Favoring Fixture Security Interest Over Prior Land Interest}

Until Ohio rejected it, one might have stated that Section 9-313's policy permitting the fixture security to defeat land interests which arose prior to the installation of the fixture similarly had won universal acceptance. ${ }^{17}$ Ohio's action, however, requires that this policy be re-evaluated.

Section 9-313's present approach seems to be based on the notion that the fixture secured party made possible the addition of new value, namely a fixture, to the land. It is unlikely-probably impossible-that prior land interests could have relied on this fixture, which was non-existent at the time their interest was created. ${ }^{18}$ Thus, it seems only fair that prior real estate interests be subordinated to the fixture security interest even though real property law treats an installed fixture as part of the real estate. ${ }^{19}$ However, the prior land interests did rely on the original condition of the land and fairness dictates that the fixture secured party should not impair it. Thus, if the fixture secured party removes the fixture to satisfy his debt, then Section 9-313 requires him to repair the land to its original condition. ${ }^{20}$

These Section 9-313 policies have an obvious equitable appeal. Indeed, the same equities have long been used to justify the favored position which the law traditionally accords to any purchase money security interest, of which the fixture security interest, typically, is an example. ${ }^{21}$ The law regards the purchase money secured party as having a special equity in the new asset

"appropriate" filing; California law apparently has no provisions specifically authorizing the filing of conditional sales contracts. $I d$. at 933 .

16. See Coogan, stupra note 9, at 1331 .

17. As recently as May 1963, Professor Gilmore assumed that the policy of $\S 9-313$ respecting priorities both to prior and subsequent real estate interests would not be questioned. Gilmore, supra note 10, at 1396 n.134.

18. The conflict between the prior construction mortgage and fixture security interest is a special case of this general problem. It differs from the more general problem in that the construction mortgagee does in fact rely on the future fixtures in making his advances. Because of the different considerations involved, it is beyond the scope of this discussion. However, see discussion by Kripke, supra note 11, at 71. Notwithstanding the somewhat different considerations involved, the writer agrees with Mr. Kripke's statement that the Code's general policies should not be refined in favor of construction lenders who "can protect themselves by searches before each advance. . . "Id. at 71 .

19. Cf. UCC $\$ 9-313$, Comment 4.

20. UCC \& 9-313(5).

21. The development of the priority accorded to purchase money security interest and the place therein of the fixture security interest is set out lucidly by Gilmore, supra note 10. 
which his funds made possible, an equity sufficient to override any claims of prior parties to the same new asset. But even if one were willing to ignore these equities and consider the problem from a strictly commercial viewpoint, 22 the basic Section 9-313 policy favoring the fixture secured party does more to encourage building and plant renovation than does Ohio's present statutory approach favoring the prior real estate mortgagee.

One might consider first an economy of rising real estate values such as the United States experienced for many years following World War II. In such an economy, the prior real estate mortgagee (unless he has been completely reckless in his loans) has an ample and increasing cushion to assure the repayment of his debt, by reason of the continuing inflation in land values. Conflicts between fixture security interest and land mortgagee are unlikely since the building and fixture in combination have, or in the future will have, suffcient value to take care of both debts. ${ }^{23}$ However, different considerations apply in a period of falling real estate values. Here, the cushion of value in the land and its improvements which protect the real estate mortgagee is constantly diminishing. In time, it will reach zero and, indeed, may become a negative quantity. This will be true even in a period of stable real estate values. For then there is a slow yet constant depreciation in improved real estate merely because of the passage of time.

Thus, where the period is one either of stable or declining real estate values, potential exists for conflict between the real estate mortgagee and the fixture secured party. In both situations the total land value constantly moves toward a point where it will be insufficient to take care of both claims. Under such conditions, the mortgagee will, understandably, be anxious to shore up the diminishing value of his mortgage lien by including within its scope the new value added to the land by a fixture. In so doing, the mortgagee must collide with the fixture secured party, whose only collateral is the very same fixture. If, in this collision, an Ohio-type rule invariably favoring the real estate mortgagee is applied, the incentive to finance plant and building improvement through the addition of new fixtures may be diminished to such an extent that the commercial need for such improvements will be frustrated. ${ }^{24}$

22. UCC \& 1-102(2) seems to require that the Commercial Code be interpreted in light of modern commercial needs.

23. In fact, in an economy of rising real estate values, it probably makes little difference what priority rule is adopted to resolve the conflict between real estate mortgagees and fixture security interests. Simply stated, there is unlikely to be any conflict between them since the rising land value and generally vigorous economy assures ultimate payment to both. Is this the answer to Professor Gilmore's query why there has been no significant amount of litigation on this subject since 1940? See Gilmore, supra note 10 at 1363 .

24. At least one Ohio writer recognized this as far back as 1939. Mr. Loren Souers then wrote:

Public policy requires that improvements on property be encouraged, and conditional sales contracts and chattel mortgages have satisfied this requirement by extending credit to purchasers. But the rule of ... [Holland Furnace Co. v. 
It should be noted, moreover, that Section 9-313's policy, even though giving supremacy to the fixture security interest, also benefits the real estate mortgagee since he inevitably obtains at least a second lien on every fixture which is installed in the building. ${ }^{25}$ From the real estate mortgagee's point of view, this second lien is a windfall; he neither expected nor relied upon it when originally advancing his funds. ${ }^{20}$ Yet, this windfall second lien becomes more valuable to the real estate mortgagee with each payment to the fixture secured party. Upon final payment of the fixture security interest, the land mortgagee's second lien actually becomes a first lien. Since the typical real estate mortgage runs for a much longer term than the typical fixture security interest, Section 9-313's approach has the long term effect of feeding new value to the prior real estate mortgagee's collateral-new value he had neither anticipated or relied upon in making his loan.

It would appear, then, that the underlying policy of Section 9-313, giving priority to the fixture security interest over both prior and subsequent land interests, is consonant with concepts of fairness and with sound commercial practice. ${ }^{27}$ Thus, it seems clear that the problems of Section 9-313 do not stem from its basic policy. Rather, the source of difficulty is the statutory machinery used to implement that policy. ${ }^{28}$ The question which must be answered is, how can this machinery be improved?

Trumbull Sav. \& Loan Co. (discussed supra in text at note 6)] leaves the status of such contracts sufficiently in doubt that such extension of credit in the future will be necessarily curtailed until some later clarification by the Supreme Court occurs.

14 Ohio Op. 164, 167.

The prior real estate mortgagee might be willing to finance new fixtures if his previous advances are substantially less than the value of the real estate. However, in this kind of case, no conflict is likely between the real estate mortgagee and fixture secured party because of the ample value cushion in the land. Thus, a priority rule to settle the conflict between them is unimportant and would be neutral in encouraging or discouraging building and plant renovation.

Where the real estate mortgagee has previously advanced funds to the full value of the land only to see his value cushion in the land being chipped away with passage of time, he is unlikely to have much enthusiasm for advancing further funds to finance the addition of new fixtures to the building. Rather, the real estate mortgagee is likely to look upon this building-one which may not even be sufficient to recoup his previous advances-as a losing proposition. Thus, from the real estate mortgagee's point of view, advancing any further funds for this building may look like throwing good money after bad. Yet, it is precisely this situation where fixture installation is most needed to renovate the building and, in the case of a commercial structure, to improve the earning potential of the debtor.

25. Fixtures become part of the real estate and, thus, ". . . as 'accessions' come automatically under the lien of the mortgage." Gilmore, supra note 10, at 1350 .

26. See discussion by Coogan \& Clovis, The U.C.C. and Real Estate Lawe, 38 IND. L.J. 535, 570 (1963).

27. See text accompanying notes 20-26 supra.

28. This accords with Professor Gilmore's assumption, mentioned supra note 17. 


\section{A New Approach to Fixture Financing}

\section{A. The Language Problem of Section 9-313: Can a Fixture Be Defined?}

Many have urged a clear-cut statutory definition of a fixture as the solution to the bulk of Section 9-313's troubles. ${ }^{29}$ This outcry is understandable, since the entire workings of Section 9-313-priority rules, place of filing, etc.- depend upon an initial determination that a fixture is involved. And nowhere does the Commercial Code set out clear guides for making that determination.

Even worse, Section 9-313(1) leaves the determination of when a chattel becomes a fixture to the individual states, which never had been particularly successful in developing consistent and workable rules on the subject. ${ }^{30} \mathrm{In}$ deed, it has been suggested that there may not even be pre-Code rules which deal with the problem in some states. ${ }^{31}$ With each state free under Section 9-313 to make its own determination of what is a fixture, an unfortunate situation has been created in what is supposed to be a uniform commercial code. Obviously any uniform law must allow for occasional variation to meet local needs. However, it is hard to imagine just what local need is sufficiently weighty to overcome a commercial need for a uniform policy dealing with fixture financing which now has nationwide implications. ${ }^{32}$ Thus, if nothing else is done to improve Section 9-313, its local determination rule as to when goods become fixtures ought to be eliminated - and this should be done even though no statutory definition for a fixture is worked out to replace it. At least with Section 9-313 completely silent on the definition of a fixture, the

29. See Braucher, The Uniform Commercial Code-A Third Look, 14 W. Res. I. Rev. 7, 21 (1962); Gilmore, supra note 10, at 1395; Coogan, supra note 9, at 1344. See also Coogan \& Clovis, supra note 26, at 569. Cf. Kripke, supra note 11, at 62-63.

30. See Coogan, supra note 9, at 1347 and authorities cited therein; and Coogan \& Clovis, supra note 26 , at 557.

31. Coogan, supra note 9 , at 1346 , suggests that Massachusetts and Ohio were in this category. The Ohio situation is also discussed by Burns, Some Specific Problems Raised by Article 9 in Ohio, 14 W. REs. L. REv. 56, 65 (1962), and Hollander, supra note 4, at 685. These gentlemen conclude that pre-Code Ohio and Massachusetts law recognized only two classes of property: personal property which was removable, and fixtures which became a part of the real estate and thus were not removable. But no intermediate category in the nature of a removable fixture such as contemplated by $\S 9-313$ was recognized. Even assuming arguendo that these gentlemen have stated the pre-Code Ohio and Massachusetts law correctly, does it follow as they seem to fear that lawyers in these states have no guidelines for applying §9-313? Section 9-313(1) merely turns to non-Code law to determine when goods become fixtures, and apparently, even Massachusetts and Ohio have law on this subject. The right to remove the fixture comes expressly from $\S 9-313(5)$ itself whether or not that right also existed before the Code.

In a later article, Coogan \& Clovis, supra note 26 , at 556-73, review this entire problem and make valuable suggestions for dealing with it.

32. See Kripke, supra note 11 , at 63 , where he describes the nationwide financing implications of fixture financing and how local fixture rules can obstruct that development. 
courts would then be required by Section 1-102(1)(c) to develop case law which, in time, probably would result in some uniform ideas on the subject. ${ }^{88}$

However, the law's experience indicates that defining a fixture, whether by judicial decision or statute, is difficult, and perhaps impossible. ${ }^{34}$ Therefore, what may be needed is an entirely new approach to the fixture financing problem : an approach which accomplishes the objectives and policies of present Section 9-313, yet does so without being tied to the definition of a fixture for its success. ${ }^{35}$

\section{B. A New Approach to the Problem of Financing Fixtures}

The present approach of Section 9-313 requires that the financier first make a decision whether the new collateral is chattel or fixture. If the decision is chattel, then purchase money security interest rules for chattels are followed. If the decision is fixture, then Section 9-313's fixture rules apply. Yet the basic policies governing the financing of fixtures and the financing of new chattels are substantially the same: both are but different aspects of the broader problem of financing any new collateral obtained by a debtor. Why, then, do the Code's specific working rules (i.e., place of filing, priority, etc.) applicable to chattels and fixtures differ ${ }^{30}$ These differences are not only inexplicable; they also have caused all the grief. Since there is no satisfactory guide for drawing the line between chattel and fixture, the result is confusion as to which set of rules to apply. Different persons are likely to reach different conclusions under the same facts. ${ }^{37}$ Conflict is inevitable.

Since the policies underlying the financing of new chattels or new fixtures coincide, why not seek to devise working rules for financing both types of collateral which are precisely the same? In such an integrated, unified system, the determination of the dividing line between chattel and fixture, presently required by Section 9-313, would become unimportant; at most, it would be an academic problem but not a practical one. Regardless of whether the collateral is chattel or fixture, the end result as to where one files and as to priorities vis-a-vis other interests would always be the same. Thus, the possibility of conflict is eliminated.

Such an ideal system is more than a theoretical idea. Indeed, it can be substantially achieved with relatively minor changes in the present Commercial Code. Suggestions for the specific statutory changes needed are set forth in the Appendix. A discussion of them follows.

33. The courts are required to interpret the Commercial Code to promote uniformity among the various jurisdictions. UCC $\$ 1-102(2)$ (c).

34. Gilmore, supra note 10, at 1396; Coogan, supra note 9, at 1347.

35. Gilmore, supra note 10 , at 1396 , envisioned this possibility. Indeed, it is his statement which inspired this paper.

36. Gilmore also noted this inconsistency. See Gilmore, supra note 10 , at 1400.

37. For example, a real estate mortgagee may find it momentarily advantageous to argue that certain collateral is a chattel rather than a fixture. Likewise a chattel mortgagee may occasionally find it worthwhile to argue that the collateral is a fixture, See Gilmore, stpra note 10, at 1392. 


\section{Integration of Filing Rules}

The most obvious difference between the Code's present working rules for chattel and fixture financing involves the place of filing the financing statement. The chattel financing statement is filed in the chattel records; the fixture financing statement is filed in the real estate records. ${ }^{38}$

This distinction could be eliminated by discarding the present requirement that fixture filings be placed in the real estate records and requiring, instead, that they be placed in the chattel records. Then all financing statements (whether referring to chattel or fixture) would be found in the same place. However, this would unduly burden land title searchers who expect and should be able to find in the real estate records information respecting any encumbrance, including fixture security interests, affecting land.

A second possibility for integrating the filing rules would be to eliminate the present requirement that chattel filings be placed in separate chattel records and to require, instead, that all chattel filings be placed only in the real estate records. Again, this would centralize all chattel and fixture filings. But this possibility too must be rejected since it would clutter the real estate records with a jumble of information, most of which would have no connection whatsoever with real estate titles. For similar reasons, a third possibility requiring all filings to be made both in the chattel and real estate records must be rejected.

The workable solution for integrating the fixture and purchase money chattel filing rules is to require fixture financing statements to be filed in duplicate: in the land records, as now required, and also in the chattel records. ${ }^{30}$ For the benefit of real estate title searchers, the requirement of duplicate filings should not change the present law requiring the fixture financing statement to contain a description of the real estate where the fixture is installed. ${ }^{40}$ The real estate description, however, will in no way affect the efficacy of the filing when placed in the chattel records. The financing statement still will contain the minimum necessary information required for chattel filings. ${ }^{41}$ It will contain some additional information (the real estate description) beyond the minimum required, but this surplusage will not impair its effectiveness as

38. UCC \$ 9-401.

39. See appendix for proposed revision of $\S 9-401(1)$. In states that have adopted the third alternative to subsection (1) of 9-401, three filings may actually be required in some cases to accomplish "duplicate" filings required by this proposal. This arises from the fact that the third alternative already requires two filings (one locally and one centrally) in some pure chattel cases. Most often this happens where business collateral owned by a debtor having a single place of business is involved. By way of example, if a furnace were installed in a commercial office building owned by a debtor having only a single place of business, then an effective chattel filing would require filing both with the Secretary of State and the local clerk or recorder. To obtain the "duplicate" filing required by this proposal, still a third filing would be needed in the office where real estate mortgages are kept.

40. UCC $\$ 9-402$ provides for such a description.

41. See UCC \$ $9-402$. 
a chattel filing. Thus, even though a court might hold ultimately that the collateral involved was a chattel, no harm would have been done. On the other hand, if a court holds the collateral was a fixture, then there equally has been a proper fixture filing containing the required real estate description. Thus, by filing doubly, the secured party has complete protection and is assured that he has filed correctly regardless of whether the collateral is ultimately held to be fixture or chattel. Similarly, any searcher of the records is put on notice of the outstanding security interest in the collateral and has no basis to argue that the filing was improper.

Quite likely, the initial reaction to this proposal is that it is a bootstrap operation which accomplishes nothing. The proposal requires only that fixture filings be made in duplicate. Pure chattel filings would be sufficient if filed singly in the chattel records. Thus, it might appear that this duplicate filing proposal still requires one to make an initial determination whether the collateral is chattel or fixture-the very determination which the proposal sought to eliminate.

Such an objection, however, presents no real obstacle when the proposal is viewed in its practical context. Under this duplicate filing rule, the practitioner really need not decide (or more likely, guess) whether a chattel or fixture is involved. All that is required is that he be aware that there is a question as to which is involved. Recognizing that such a question exists is far easier than reaching the firm decision presently required by Section 9-313 as to where one draws the dividing line between chattel and fixture. Consider, for example, the problem of a built-in gas oven, the gas lines and exhaust pipes of which are imbedded in the walls. Few practitioners would dare state definitely whether the oven with its gas lines and exhaust pipes will be held to be chattel, fixture, or some of both. But they would not have much difficulty in realizing that there is a question as to whether a chattel or fixture is involved. Once there is awareness that a question exists, the practitioner may file in duplicate and be assured of complete protection, since his double filing satisfies both the chattel and fixture filing requirements. Indeed, any official comments accompanying this proposal should point out the desirability of duplicate filings with respect to any collateral where there exists the slightest doubt whether it is fixture or chattel. ${ }^{42}$ Undoubtedly, even under present Section 9-313, careful secured parties already are filing in duplicate in these borderline situations. ${ }^{43}$ That which careful persons are already doing for the purpose of reducing the potential for conflict now inherent in present Section 9-313 ought to be incorporated into the actual structure of that section.

It should be emphasized that this proposal reverses the Code's present rule permitting fixture filings to be effective if made singly in the real estate records. Where a fixture is involved, duplicate filings-once in the chattel records and

42. This has already been done in similar situations. See, e.g., UCC $\$ 9-103$, Official Comment 2.

43. Coogan, supra note 9 , at $1341-42$ has encouraged the practice. Undoubtedly, this same advice has been repeated by many others. 
also in the land records-would be essential to accomplish perfection. But the double filing required in the fixture situation happily also meets the filing requirements for a chattel if a court later declares the collateral to be chattel. Thus, by filing doubly, the financier completely avoids even the possibility of attack on the ground that his filing may have been erroneous. Under this proposal, the only single filing which could be effective is one made in the chattel records provided that a court later agrees that the collateral was, in fact, a chattel. Thus, the necessary effect of this proposal is to subject any security interest which is filed singly in the chattel records to attack on the ground that it was a fixture and therefore required a double filing. As such, the motive is strong for the financier to eliminate this possibility for attack: on his security interest by filing doubly in any case where there is the slightest possibility that a court might later declare the collateral a fixture. It is this strong motive to file doubly in those doubtful cases and thereby obtain complete filing protection which assures that this proposal is workable in practical day to day operations.

The simple step of requiring duplicate filing for fixture security interests, which in turn motivates duplicate filing whenever the nature of the collateral is in doubt, would thus go a long way to reduce many problems now existing by reason of Section 9-313. By and large, it would eliminate the confusion and conflict which now arise under Section $9-313$ by reason of a search in the wrong set of records because the financier guessed that the collateral was fixture whereas the searcher guessed that the collateral was a chattel. As a practical matter, regardless of whether the chattel or land records were searched, an outstanding security interest in a particular item of collateral would likely be discovered. The searcher would be made aware that the collateral, be it chattel or fixture, could be dealt with only subject to the outstanding prior security interest. In fact, under the proposal only one possibility exists for conflict because the searcher checks the wrong records; namely if the financier, satisfied that the collateral is pure chattel, files only in the chattel records, while the searcher, believing the item to be a fixture, examines only the real estate records. For this situation to arise in a practical context, the financier must be so certain that the collateral is pure chattel that he feels no need for a protective double filing; and the searcher must be equally certain that the collateral is fixture, to the degree that he sees no need even to check the chattel records. Just what collateral might raise such diametrically opposite certainties among practical businessmen or lawyers is, indeed, difficult to imagine.

\section{Integration of the Priority Rules}

Requiring fixture security interest filings to be duplicated in the chattel records would be a long step toward a workable integrated financing system wherein the distinction for financing purposes between chattel and fixture is eliminated. However, by itself, it still falls short of that goal, as illustrated by the following example. 
$\mathrm{X}$ loans money to the Widgett Manufacturing Company. To secure its.loan, $\mathrm{X}$ obtains and promptly perfects both a real estate mortgage on Widgett's real estate and a security interest in all of Widgett's present and after-acquired personal property. Thereafter, Widgett Manufacturing Company realizes that its operations require more hot water. Accordingly, Widgett orders from $\mathrm{F}$ a new hot water tank. The tank is then installed by F. After its installation, F and Widgett execute a security agreement plus several financing statements containing a description of the real estate where the tank is installed to cover the purchase price. The financing statements are then promptly filed in both the chattel and real estate records.

It will be noted that $F$ has abided by the above proposal to file financing statements in duplicate wherever doubt exists whether the collateral-the hot water tank-will ultimately be held to be chattel or fixture. Even so, because the Commercial Code's present priority rules are different for chattels than they are for fixtures, the priority contest between $X$ and $F$ as to the hot water tank still will depend entirely on whether the hot water tank is held to be a fixture or a chattel. If held to be a chattel, $\mathrm{F}$ will prevail as the holder of a purchase money security interest which was perfected within ten days after Widgett obtained possession thereof. ${ }^{44}$ If held to be a fixture, $\mathrm{X}$ will prevail as a prior real estate mortgagee who defeats any fixture security interest which arose after installation of the fixture. ${ }^{45}$

Many other examples could be presented. ${ }^{46}$ Each would point to the fact that an integrated system which eliminates or minimizes the distinction between fixture financing and purchase money chattel financing must have common priority rules as well as common filing rules.

To achieve this objective, it is probably best to revise the present fixture priority rules to make them coincide with the corresponding purchase money chattel rules. Presently, the chattel rules permit the purchase money security interest to prevail over any prior or subsequent interest in the chattel if perfection is accomplished within ten days after the debtor obtains possession of the chattels. ${ }^{47}$ Accordingly, Section 9-313 should be amended to require a similar ten day filing for the fixture security interest to obtain protection against all prior and subsequent land claimants. ${ }^{48}$ Further, to assure consist-

44. UCC \$ 9-312(4).

45. UCC \& 9-313(3).

46. See Coogan, supra note 9, at 1330.

47. UCC \&\$ 9-301(1-2) give the purchase money chattel interest priority over purchasers, transferors, and lien creditors. UCC $\$ 9-312(4)$ gives priority over other secured parties. Slightly different rules govern where purchase money security interests int inventory collateral are involved. See UCC $\S 9-312(5)$, which requires notice plus immediate filing to defeat other security interests in inventory collateral. See also UCC $\$ 9-307$, where a buyer in ordinary course of inventory collateral can defeat a security interest therein. However, it is hard to imagine a situation where fixtures might ever be looked upon as inventory. As such, it is assumed that integrating the fixture rules with non-inventory purchase money chattel rules is all that is practically required to achieve the underlying objectives of the proposals set forth in this article.

48. See appendix for proposed revision of $\$ 9-313(2)$. 
ency, Section 9-313 must also make clear that this supremacy is reserved only for a purchase money fixture security interest as opposed to a non-purchase money fixture security interest which, by chance, happened to have been perfected within the ten day period. ${ }^{49}$

In the chattel situation, there is one exception to the supremacy accorded to the purchase money security. interest filed within a ten day period. That exception is in favor of a bona fide purchaser of the chattel who purchases the chattel before actual perfection of the security interest, even though within the ten day grace period normally allowed for perfection. ${ }^{50}$ Accordingly, a similar exception in favor of bona fide purchasers of the land should be written into Section 9-313 with respect to the fixture security interest. ${ }^{61}$

These changes would little affect the present Section 9-313 result with respect to persons obtaining interests in the land subsequent to the installation of the fixture. ${ }^{52}$ Among such persons, only the judgment lien creditor would have his rights affected, and then only slightly. Under present Section 9-313, such a subsequent lien creditor has priority so long as his lien was obtained at any time prior to perfection; under the proposed change, the lien creditor would be defeated by a fixture security interest which was filed within the ten day grace period.

On the other hand, these changes in the fixture priority rules would very markedly affect Section 9-313's approach respecting claimants whose interest in the land arose prior to the installation of the fixture. Presently, the question whether the prior land claimant defeats the fixture security interest depends entirely upon the timing of the attachment of security interest. The time of filing the security interest plays no part whatsoever in this determination. So long as the fixture security interest attaches before installation of the fixture, it invariably defeats prior land interests. ${ }^{53}$ On the other hand, if the security interest attaches after installation of the fixture, it never defeats prior land interests. ${ }^{54}$ These priority rules are based on the notion that prior land interests can never be prejudiced by a non-filing. The assumption is that prior land interests could not have relied on a fixture which is later installed. Thus, the theory is that the fact of filing or non-filing of the fixture security interest is of no significance with respect to their claims. ${ }^{55}$

49. Ibid. In the overwhelming number of cases, fixture financiers will also be purchase money financiers. See Gilmore, supra note 10, at 1389 . However, fixtures may be a source of collateral to persons not involved in financing its acquisition. Thus, it should be made clear that such persons are not entitled to the priorities peculiar to the purchase money security interest.

50. UCC \$ 9-301(1) (c) and (2).

51. See appendix for proposed revision of $\S 9-313(2)$. The proposal also makes it clear that a prior mortgagee who subsequently gives new value is to be deemed a purchaser.

52. See proposed revision of $\S 9-313(3)$ in appendix.

53. UCC \& 9-313(2).

54. UCC $\S 9-313(3)$.

55. UCC \& 9-313, Official Comment 4. 
As a realistic matter, however, there certainly are some situations where prior land interests do rely on fixtures which are later installed. Quite true, there is no reliance on the nonexistent fixture when the prior land interest extends his credit. ${ }^{56}$ But prior land interests may rely on the fixture at a later time, particularly when deciding whether to institute foreclosure proceedings. ${ }^{67}$ Certainly many real estate mortgagees have withheld foreclosure proceedings on the assumption that the additional value imparted to the land by a subsequently installed fixture is now subject to his mortgage lien. Yet such apparently justifiable assumptions may be frustrated because of Section 9-313's rule that no public notice (filing) of a fixture security interest is necessary to defeat a prior land interest. This could be avoided, in most instances, by requiring the fixture security interest to be filed within ten days to assure his supremacy over prior land interest.

Moreover, it is difficult to follow the logic of present Section 9-313's approach where a security interest which attaches before installation always defeats the prior land interests while a fixture security interest which attaches after installation never defeats them. The party affected, namely the prior land interest, rarely knows-indeed he probably has no way of knowing-the precise time when the fixture security interest attached. ${ }^{58}$ Realistically, the prior land interest is aware only of one fact: whether the fixture is or is "not installed on the land. If it is there on the land, the prior land interest is likely to rely on it in his future actions unless he is forewarned that the fixture is subject to another person's paramount security interest. The time of attachment of the fixture security interest, being a matter entirely beyond the prior land interest's knowledge, hardly can be expected to govern his future actions. ${ }^{60}$ Therefore, a requirement that fixture security interests be filed within ten days to defeat prior land claimants will result not only in common priority rules for fixtures and chattels, but also will remedy the inequity now arising from Section 9-313's emphasis on time of attachment.

Another rather difficult problem remains in integrating the priority rules with respect to bona fide purchasers. The Commercial Code's present chattel rules permit the good faith purchaser for value to defeat the unperfected purchase money chattel security interest only if he also receives delivery of the chattel before perfection. ${ }^{60}$ If common fixture and chattel rules are to be achieved, at first glance it might seem that some similar delivery requirement should be inserted in the fixture priority sections.

56. This is not so when a construction mortgage is involved. With reference to the special situation involving the construction mortgage, see supra note 19.

57. Coogan, supra note 9 , at 1333 , also noted this fact.

58. Attachment of a security interest occurs when the last of the following takes place, although they need not occur in any particular order: (1) agreement to give the security interest, (2) value extended by the secured party, and (3) the debtor obtaining rights in the collateral. See UCC \$ 9-204(1).

59. Hollander, supra note 10 , at 688 , also noted this problem.

60. UCC $\$ 9-301(1)(c)$. See also UCC § 9-301, Official Comment 4. 
One readily grasps the idea of a "delivery" when dealing with chattels. However, the concept is elusive in the land situation. Does it entail delivery to the purchaser of physical possession of the land? Or would it suffice if there were merely delivery to the purchaser of the deed required under real property law in most real estate title transactions? Rather than seek an answer to these questions, perhaps a more desirable solution is to eliminate the "delivery" requirement entirely-in both the chattel and the fixture situation." ${ }^{61}$ Why should not a purchaser, whether of goods or land with fixtures installed, be fully protected merely on the basis that he gave value in good faith and without actual or constructive notice of an unperfected security interest? To impose on such a good faith purchaser the further requirement that he also obtain delivery gives an unwarranted advantage to the secured party. The secured party, by perfecting promptly and thereby giving constructive notice of his security interest, could have fully protected himself and likely avoided loss to the purchaser. Where the secured party fails to do this, it does not seem that he should be able to defeat a purchaser, who gives value in good faith and relies on the apparently unencumbered status of the property, merely because the purchaser has not received delivery of the property as well.

The purchaser's failure to receive delivery of the property, of course, may have legal consequences beyond Article 9 of the Commercial Code. It may give rights to the seller's creditors under the law of fraudulent transfers. ${ }^{62}$ Or, it might work an estoppel against the purchaser in favor of persons who may have relied on the seller's continued possession. ${ }^{63}$ However, absent facts showing such an estoppel or fraud, no justifiable reason exists for making a bona fide purchaser's rights to either chattels or land dependent on delivery in order to defeat an unprotected security interest therein.

\section{E. The New Approach Applied to Financing Structural Materials}

Students of Section 9-313 realize that the line between chattel and fixture is not the only one which it is necessary to draw. The section also necessitates a distinction between chattel and structure. Putting it more precisely, Section 9-313(1) makes it clear that Commercial Code security interests are not even available with respect to goods which become a part of a structure such as cement, bricks, etc. Any lien rights desired for the financing of such goods must, instead, be acquired under real property law-most likely as a real estate mortgage or a real estate mechanics lien.

Although it may be easier to determine when chattels become a part of the structure than when chattels become fixtures, many cases can be suggested

61. See appendix for proposed revision of \$ 9-301(1) (c).

62. Where a buyer permits his seller to retain possession of the sold property, then the sale may be deemed a fraudulent transfer. See Williston, Sales $\S 351$ passim (rev. ed. 1948). Cf. UCC \$ 2-402.

63. See 19 Am. JUr. Estoppel, $\S 68$, at 696 (1938); see also Williston, Sales $\S 349$ (rev. ed. 1948); cf. UCC § 2-403. 
where the precise placement of this chattel-structure line will present diffculty. ${ }^{64}$ By way of example, does paneling tacked to a wall retain its characteristics as chattel or does it become incorporated into the structure? Indeed, what constitutes a structure even may be unclear. For instance, is a fence or a telephone pole a structure?

Under present Section 9-313, one first must determine what constitutes a structure and then determine whether the chattel in question has been incorporated therein in order to resolve finally whether an Article 9 security interest in such collateral is possible. To avoid these obvious problems, it seems advisable to apply the new approach suggested for financing fixtures also to those goods which become part of the structure-to treat such goods precisely as if they were fixtures, and to allow the purchase money financier to obtain security interests under the Code by complying with the integrated filing requirements and priority rules suggested above. ${ }^{65}$ If this were done, the end result would be a unified system for the purchase money financing of all goods. So long as the collateral starts out as chattel, then the financier, by using the system, would be certain of obtaining his purchase money priority with respect to the goods regardless of any future determination as to whether the goods (1) retain their characteristics as pure chattels, or (2) are so affixed to the real estate as to become fixtures, or (3) are so incorporated in the real estate as to become part of a structure. Similarly, third parties would be spared the difficulty of drawing these lines since the working rules of the system affecting them (filing, priority, etc.) dictate the same results regardless of which of the three categories is involved.

This proposal, of course, would not prevent financiers from obtaining liens and mortgages by traditional real property law methods because of the addition of structural goods. The proposal merely adds an additional mechanism for financing this kind of collateral. But, with the inclusion of this mechanism, a completely integrated system for the purchase money financing of any collateral which begins life as chattel can be achieved. Hopefully, such an integrated financing system would end the difficult problems now raised by the necessity of drawing lines between chattel, fixture, and structure.

\section{Some Clarification Needed in Section 9-313}

Problems other than those raised by the necessity of drawing a line between fixture and chattel also need clarification and change in Section 9-313.65a Although the suggestions for clarification of Section 9-313 which follow would

64. Gilmore, supra note 10 , at 1390 , says that no statutory formula could ever be devised to place this line. Interestingly, he goes on to state that under present $\S 9-313$ there is no practical necessity to do so.

65. See appendix for proposed revision of $\$ 9-313(1)$. Obviously a secured party with a security interest in structural materials should be prohibited from removing them as a foreclosure device. See discussion infra, Part III.

65a. See Kripke, stipra note 11. 
complement nicely the above proposal for an integrated financing system, the question of their desirability stands independently of that proposal.

\section{A. Judicial Foreclosure in Lien of Removal of Fixtures and Structural Materials}

Where the fixture secured debt is not paid, removal of the fixture seems to be the favorite means of foreclosing on the fixture security interest. Indeed, from the literature, one might get the impression that it is the only foreclosure method now authorized by Section $9-313 .{ }^{66}$ However, if the fixture secured party's interest is junior to some other interest in the real estate, he has no right to remove the fixture under present Section 9-313(5). And in many instances, the fixture secured party may prefer not to exercise his removal rights. This will occur often where the fixture has little or no value apart from the building in which it was installed. An example might be an elevator designed for a particular building. Dismantled from the building, the elevator probably has only junk value. On the other hand, the union of building and fixture make for a useful and economically valuable whole. Indeed, in most situations, the combination (fixture plus building) is worth more than the sum of the individual components.

Where the fixture secured party has no right of removal or, having the right, prefers not to exercise it, the Code, as it now stands, probably authorizes the fixture secured party to employ judicial foreclosure proceedings to enforce his security interest. ${ }^{67}$ However, this result is not clear, and the right to resort to judicial foreclosure ought not to be left to doubt. Clarifying amendments to Section $9-313$ or its official commentary are obviously needed. ${ }^{68}$

But the problem cuts deeper and will not be solved entirely by an amendment merely making it clear that judicial foreclosure of a fixture is an optional alternative to foreclosure by removal. There are situations where a fixture secured party should actually be required to use judicial foreclosure proceedings even though he has the right of removal and wishes to exercise that right. An example might be where a secured party, having a paramount security interest in a heating system in a large apartment building, sought to remove it during the dead of winter. The injurious effect of such action on the tenants

66. See, e.g., Gilmore, supra note 10 , at 1391 where he states that ". . . as a practical matter the only goods as to which the $9-313$ priority is worth having are goods which can be removed without seriously damaging the structure." See also Coogan \& Clovis, supra note 26 , at 56 , where the authors emphasize removeability as the major attribute of a fixture.

67. UCC $\S \S 9-501(1), 1-106(2)$. Undoubtedly these would be equitable proceedings where the court would have broad powers to fashion a decree to meet the peculiar circumstances of the case. Thus, the court might turn to receivership to collect rents and profits which would then be applied on the security interest. Or, in appropriate cases, it might even order a sale of the land subject to senior interests. Compare Coogan, supra note 9 , at 1327 , who states that a junior secured party has no effective foreclosure rights except by consent of the senior land interests.

68. See proposed revision of $\$ 9-313(5)$ in appendix. 
of the apartment building is obvious. Common sense, therefore, suggests that some limitations be placed on the absolute right of a prior fixture security interest to remove. At least, judicial foreclosure should be required where removal would adversely affect health or safety. If not provided for in Section 9-313, the limitation is one likely to be imposed by the courts through some "back door" means. ${ }^{68}$

Such judicial prohibition on removal probably should also be authorized where removal would cause irreparable harm to the rights of other persons having interests in the land; or where the economic value of such other interests would be disproportionately diminished by the removal. A fairly clear example would be the attempted removal of structural materials by a secured party claiming a paramount security interest therein under the proposals set out in Part II of this paper. Since removal of the structural materials would destroy the economic usefulness of the building, it should be prohibited. Another example would be the attempted removal of an elevator from a skyscraper. Such removal would shockingly diminish the economic value of the remaining building for those having interests therein. In both cases, therefore, the fixture secured party should be denied his right to remove; instead, he should be required to use judicial foreclosure proceedings. This will bring into play the full equitable powers of the court for the purpose of preserving the value of the real estate as an integrated economic unit and maximizing the recovery for all parties having an interest in the real estate. ${ }^{70}$ Limiting the right to remove in no way detracts from the fixture secured party's paramount security interest in his collateral. It merely requires him to enforce his security interest in a sensible and equitable fashion. ${ }^{71}$

69. Gilmore, sipra note 10 , at 1361, speculates that the vicissitudes of the New Jersey courts in refusing to allow removal of needed apartment house fixtures was to avoid having ". . . a substantial part of the population condemned to camping out on the New Jersey marshes without heat, light, or refrigeration [thus] the courts ordered that the essential equipment be left in the apartment houses."

70. As suggested in note 67 supra, this might be receivership in some cases. In other cases, an appropriate sale of the land might be ordered.

Equity courts have in the past apparently been willing to take jurisdiction over a whole asset to maximize recovery to individual interests therein. For example, see National Park Bank v. Goddard, 131 N.Y. 494, 30 N.E. 566 (1892), involving the different claims to individual components (linings, buttons, etc.) of completed garments. See also Joralman v. McPhee, 31 Colo. 26, 71 P. 419 (1903), involving one set of liens on land and another on the improvements thereto. The court sold the whole under a decree prohibiting separate removal of the improvements.

71. If fixture security interests can and, in some circumstances, must be foreclosed by judicial means, marshaling problems inevitably will arise. Section 9-313 can lead to situations where there is one set of liens (security interests) on the fixture and another set of liens on the total real estate. Yet, many judicial foreclosure proceedings will result in a sale of the total real estate (fixture and building combined) and the realization of only a single fund of money to be allocated between the two sets of liens. The question of how this allocation should be made can raise difficulties.

Such problems, however, are not new to the courts; and solution can probably be left to their sound discretion. Similar situations have been so treated by the Code. See UCC 


\section{B. The Exchange Problem: New Fixtures for Old}

When an old fixture is exchanged for a new one, many real estate mortgagees are likely to feel that Section 9-313 deals with them most unfairly. To illustrate the point, consider the case where an older furnace is removed and replaced by a new furnace on which a paramount fixture security interest is perfected. If the fixture secured party removes the furnace in order to collect on his debt-as Section 9-313 now permits-then the real estate mortgagee is likely to feel that his security has been unfairly depleted. He is likely to reason that he originally had a perfectly good mortgage on a building which was made economically useable and valuable by an older yet workable furnace. However, that furnace is now gone, having been removed to make room for the new furnace. When the fixture secured party later removes the new furnace as well, the building may be rendered virtually useless. Under such conditions, the real estate mortgagee is likely to damn Section 9-313 and call for its repeal. ${ }^{72}$ If Section 9-313 actually creates such conditions, one could be quite sympathetic with the real estate mortgagee's despair. However, it does not seem likely that the Commercial Code can be construed to be quite such a villain.

The real estate mortgagee's apparent plight really involves the question of waste. It raises the question of how the law should deal with a fixture secured party who, in the process of installing his fixture, wrongfully damages or wrongfully removes property subject to another person's security. Prior to the Commercial Code, the few courts which dealt with this problem had little trouble in reaching an equitable solution. ${ }^{73}$ Usually the approach was to weigh the increase in value of the building attributable to the addition of the new fixture against the value of the older fixture which had been removed. If the balance was in favor of the fixture claimant, priority to the new fixture was usually awarded to him. ${ }^{74}$ If the balance was in favor of the land mort-

\$ 9-311 (Comment). On the other hand, some guide lines written into the official comments accompanying $\$ 9-313$ might be helpful. Probably the fairest approach is to order distribution of the fund according to a ratio which takes into consideration the value added to the real estate by the fixture on the date of foreclosure compared to the total value of the real estate. By way of example, assume a building valued at $\$ 90,000$ without a particular fixture. With fixture installed, the value of the total real estate is $\$ 100,000$. Obviously, the value added by the fixture is $\$ 10,000$, or $10 \%$ of the total. Upon a judicial foreclosure sale, ninety percent of any fund realized would be distributed to persons having claims against the total real estate; ten percent would be distributed to persons having claims against the fixture. For a case following this approach, see Joralman v. McPhee, supra note 70, where the fund was allocated to land liens and to improvement liens according to their respective values.

72. The author's personal feeling is that this kind of thinking contributed more to Ohio's repeal of $\$ 9-313$ than any other single factor.

73. See, e.g., Campbell v. Roddy, 44 N.J. Eq. 244, 14 Atl. 279 (1888). See also Annot., 13 A.L.R. 448, 468 (1921).

74. E.g., Keil Motor Co. v. Home Owners Loan Corp., 43 Del. (4 Terry) 322, 47 A.2d 164 (1941); Frigidaire Sales Corp. v. Katz, 29 Ohio N.P. (n.s.) 595 (1931). 
gagee's older fixture, the priority as to the new fixture usually went to him. ${ }^{75}$ In any case, damages for waste were always available to the aggrieved mortgagee. $^{76}$

The fact that Section 9-313 makes possible a top-priority fixture security interest can hardly be read as a license for fixture secured parties to destroy the property or security of others. Rather, it seems more likely that aggrieved real estate mortgagees can still obtain appropriate relief against such wrongdoing secured parties under Section 1-103, declaring general rules of law and equity to be supplements to the Commercial Code. Nevertheless, the actual language of Section 9-313 does not make this completely clear, and should, therefore, be modified to allay the real estate mortgagee's fears that his security may be unjustly imperiled. More specifically, clarifying amendments should be added to state that Section 9-313 does not authorize a fixture secured party to commit waste. ${ }^{77}$ Such amendments should also: (1) expressly empower a court where waste has been wrongfully committed to grant appropriate equitable relief, including the power to subordinate a fixture security interest in whole or in part where the circumstances so require and (2) give discretion to a court to issue a money award against the wrongdoing secured party in lieu of subordination. Moreover, any such money award should be deemed an equitable order, punishable by contempt, and should be awarded in lieu of subordination only when the court is satisfied that collection is assured.78

\section{SUMMARY}

The Code's present triple financing system, which is dependent on the distinction between chattel, fixture and structural goods, has created much confusion. The proposal for an integrated and unified purchase money collateral financing system suggested in this paper is designed to end that confusion by eliminating the need to draw the uncertain lines between chattel, fixture and structural goods for financing purposes. To achieve this single financing system, filing and priority rules for fixture and structural goods security interests and the comparable rules for chattels should be made to coincide. In particular, this goal can be achieved practicably for the filing rules by requiring fixture and structural goods filings to be duplicated both in the chattel and real estate records.

The priority rules can be unified by :

a. Requiring fixture and structural goods security interests to be filed within ten days from the time the debtor receives possession in order to

75. E.g., Murray Co. v. Jacksboro Oil \& Milling Co., 205 S.W. 517 (Tex. Civ. Ap. 1918).

76. Holland Furnace Co. v. Bird, 45 Wyo. 471, 21 P.2d 825 (1933) ; Fisk v. Peoples Nat'l Bank, 14 Colo. App. 21, 59 P. 63 (1899).

77. See appendix for proposed revision of $\$ 9-313(6)$.

78. Ibid. 
obtain a supremacy over the land interests (whether arising prior to or subsequent to the installation of the fixture) other than bona fide purchasers of the land.

b. Giving to bona fide purchasers of the land priority over any fixture or structural goods security interest which was not filed at the time of the purchase.

c. Eliminating from the present chattel rules the requirement that a bona fide purchaser must receive delivery of the chattel in order to defeat an unperfected purchase money security interest therein.

Certain misunderstandings respecting the present effect of Section 9-313 of the Uniform Commercial Code, also need clarification. In particular, Section 9-313 should be amended to make it clear that the fixture secured party may use judicial proceedings or removal for the purpose of foreclosing his secured interest. In cases where removal of the fixture would affect health, welfare and safety or in cases where removal would cause irreparable harm to other interests in the land, then judicial foreclosure proceedings should be made mandatory. Section 9-313 also should be clarified to state that a fixture secured party is not authorized to commit waste or unlawfully to impair the security of others.

\section{ApPENDIX}

Proposed Revision of Article 9 of U.C.C.

Changes or additions in the Commercial Code are indicated by italics, deletions by strikeūiuts.

$$
\text { U.C.C. } 9-301
$$

(1) Except as otherwise provided in subsection (2), an unperfected security interest is subordinate to the rights of

(a). (No Change).

(b). (No Change).

(c). in the case of goods, instruments, documents and chattel paper, a person who is not a secured party and who is a transferee in bulk or other buyer not in ordinary course of business to the extent that he gives value and recaives delivery of the collateral without knowledge of the security interest and before it is perfected;

(2) (No Change).

(3) (No Change).

$$
\text { U.C.C. } 9-313
$$

(Completely Revised)

Priority of Security Interests in Goods Which Become Part of Real Estate

1. The rules of this section apply to fixtures which term shall include: (a) fixtures and (b) goods incorporated into a structure in the manner of lumber, bricks, tile, cement, glass, metal work and the like. This Act does not 
prevent creation of an encumbrance upon fixtures or real estate pursuant to the law applicable to real estate.

2. A purchase money security interest in fixtures which is perfected before or within ten days after the goods which are or which are to become the fixtures come into the possession of the debtor takes priority as to the fixtures over the clains of all persons who have or subsequently obtain an interest in the real estate except a purchaser who within said ten day period acquires any interest in the real estate to the extent that said purchaser gives value without knowledge of the security interest and before it is perfected. A creditor with a prior encumbrance of record on the real estate who subsequently gives value is a purchaser to the extent of the subsequent value extended.

3. A security interest in goods which are or are to become fixtures and which is not entitled to the priority rule stated in subsection 2 is subordinate to any person with an interest in the real estate at the time that the goods come into the possession of the debtor. Such security interest is prior to all persons acquiring interests in the real estate subsequent to the time that the goods come into the possession of the debtor except

(a) a subsequent purchaser for value of any interest in the real estate; or

(b) a creditor with a lien on the real estate subsequently obtained by judicial proceedings; or

(c) a creditor with a prior encumbrance of record on the real estate to the extent that he makes subsequent advances

if the subsequent purchase is made, the lien by judicial proceedings is obtained, or the subsequent advance under the prior encumbrance is made or contracted for without knowledge of the security interest and before it is perfected. A purchaser of the real estate at a foreclosure sale other than an encumbrancer purchasing at his own foreclosure sale is a subsequent purchaser within this section.

4. When under subsections (2) and (3) and (4) a secured party has priority over the claims of all persons who have interests in the real estate, he may, on default, subject to the provisions of Part 5 and subject to Subsection 5 , remove his collateral from the real estate but he must reimburse any encumbrancer or owner of the real estate who is not the debtor and who has not otherwise agreed for the cost of repair of any physical injury, but not for any diminution in value of the real estate caused by the absence of the goods removed or by any necessity for replacing them. A person entitled to reimbursement may refuse permission to remove until the secured party gives adequate security for the performance of this obligation.

5. Notwithstanding Subsection 4, a court may in appropriate circumstances prohibit a secured party having the right to remove his collateral from so doing and may instead require the secured party to enforce his security interest in the collateral by judicial procedures.

6. This section does not authorize a secured party unlawfully to commit waste with respect to real estate or unlavefully to impair the security of others 
in the real estate. Where a secured party has unlawfully committed waste or unlawfully impaired the security of another, then a court may

(a) Subordinate in whole or in part the security interest of the secured party to the interest in the land of the aggrieved party, or

(b) order the secured party to pay damages to the aggrieved party. Such order shall be issued only where collection thereof seems reasonably assured. Until the order is fully complied with, the cont shall retain jurisdiction to issue other appropriate relief, or

(c) issue any other appropriate order.

\section{U.C.C. $9-401$}

First Alternative Subsection (1)

(1) The proper place to file in order to perfect a security interest is as follows :

(a) In addition to the filing required by paragraph (b), when the collateral is goods which at the time the security interest attaches are or are to become fixtures, then in the office where a mortgage on the real estate concerned would be filed or recorded;

(b) (No Change).

Second and Third Alternative Subsection (1)

(1) The proper place to file in order to perfect a security interest is as follows :

(a) (No Change).

(b) in addition to the filing required by paragraphs (a) and (c), when the collateral is goods which at the time the security interest attaches are or are to become fixtures, then in the office where a mortgage on the real estate concerned would be filed or recorded;

(c) (No Change).

(2) (No Change).

(3) (No Change).

(4) (No Change). 


\section{THE YALE LAW JOURNAL}

\author{
Robert A. Burt \\ JoHN A. KosKINEN \\ Elltott J. Werss \\ William C. Whitrord \\ Note \& Comment \\ Editors
}

Jonathan A. Ater

EDWARD L. Barlow

RICHARD J. BraEMER

Dennis K. Bromiley

Michael A. Brush

Donald C. Christ

Joseph D. Clayton

EDWARD R. COHEN

Charles J. Donatue, Jr.

Roger D. Feldaran

Stephen R. Field

Thomas K. GiLHOOL

Sherwin M. Goldman

JaMres S. Gordon
Peter L. Strauss

Editor-in-Chief

Monroe E. Price

Executive Editor

\author{
ROBERT E. COOPER \\ STEVEN M. UMIN \\ Article \& Book \\ Review Editors \\ ROGER W. TOMPKINS \\ Managing Editor
}

JoHN GRIFFITHS

Paul Grossaran

Michael F. Halloran

Charles R. Halpern

JoHn D. Hofrman

Michael J. HoRowitz

ALAN D. JACOBSON

HOWARD J. KasLOW

RICHARD A. Katzive

JoHN L. KrafT

Martin D. Krali.

Martin E. Lowy

Rod McMafan

\author{
Josepr D. Mandez \\ Daniel Marcus \\ Leonard M. Marks \\ ANITA S. Martin \\ Charles M. Natean \\ Barbara H. Paul \\ Edward A. Perelt. \\ David A. RAHM \\ OWen J. Sloane \\ George P. Smith \\ WILLARD B. TAYLOR \\ Allan A. Tuttle \\ Michaei A. VARet \\ JoHN A. Young
}

EArL W. SHAPIro

Business Manager
Alice C. TEars

Business Secretary

\section{CONTRIBUTORS TO THIS ISSUE}

Charles A. Retch. B.A. 1949, Oberlin; LL.B. 1952, Yale University.

Morris G. Shanker. B.S.E.E. 1948, Purdue University; M.B.A. 1952; J.D. 1952, University of Michigan.

Nicholas A. Vonneuman. LL.D. 1932, University of Budapest; B.A. 1949; M.C.L. 1951, George Washington University.

Surya P. Sharma. LL.M. 1956, University of Delhi; LL.M. 1960; J.S.D. 1964, Yale University. 